\title{
Mapping of raw materials and habitats in the Danish sector of the North Sea
}

\author{
Jørn Bo Jensen, Sara Borre, Jørgen O. Leth, Zyad Al-Hamdani and Laura G. Addington
}

In the summer of 2010, the Geological Survey of Denmark and Greenland (GEUS) mapped the potential raw materials and substrate types, over large parts of the Danish economic sector of the North Sea, in cooperation with Orbicon A/S. The mapping was carried out for the Danish Nature Agency; it is part of the general mapping of raw material resources within the territories of the Danish state and forms part of the input for the implementation of the European Union's Marine Strategy Framework Directive. The purpose was (1) to provide an overview of the distribution, volume and composition of available raw materials and (2) to identify, describe and map the distribution of the dominant marine bottom types.

\section{Methods}

During the first part of the field work a single beam echo sounder for bathymetrical data, a side scan sonar for mapping the seabed surface as well as a chirp (1-10 kHz) and a sparker $(1 \mathrm{kHz})$ were used to map the layers below the seabed with up to $50 \mathrm{~m}$ penetration. After preliminary interpretation, the acoustic data acquisition was followed by sediment sampling using a vibrocorer with up to $6 \mathrm{~m}$ penetration and a grab sampler in order to investigate the characteristics of the sediments. In addition, the seabed was filmed using a video camera mounted on a remotely operated vehicle (ROV) to document the seabed sediment substrate and benthic fauna. The field work was divided

Fig. 1. Map of the economic sector of the Danish North Sea showing the seismic grids and sampling positions in the combined raw material and marine bottom-type mapping carried out in 2010. A: phase 1 area. B: phase 2 area. C: phase 3 area. into three phases (Fig. 1, Table 1): phase 1: mapping of both raw materials and bottom types, phase 2: mapping of bottom types alone and phase 3: geological mapping.

\section{Bathymetry and geological model}

The data from the phase 1 area made it possible to map the bathymetry and develop a geological model for the area. The bathymetric data show a NW-SE-trending ridge 25-30 m below present sea level interpreted as the offshore continuation of the Main Stationary Line (MSL) that formed during the last glacial maximum (Fig. 2A; Houmark-Nielsen \& Kjær 2003). The high area comprises the core areas of Jyske Rev and Lille Fisker Banke. North of the MSL a series of ridges trending NNE-SSW that are $20-40 \mathrm{~km}$ long and $5-10 \mathrm{~km}$ broad dominate the bathymetry. The crests of the ridges are $18-24 \mathrm{~m}$ b.s.l. and the troughs around $40 \mathrm{~m}$ b.s.l. These large ridges are interpreted as early Holocene giant tidal sand ridges. Backstripping shows the pre-Holocene transgression surface and accentuates the MSL (Fig. 2B). South of the MSL the bathymetry shows a gentle south-western slope, which we interpret as drowned sandur deposits that formed in front of the melting Scandinavian ice sheet.

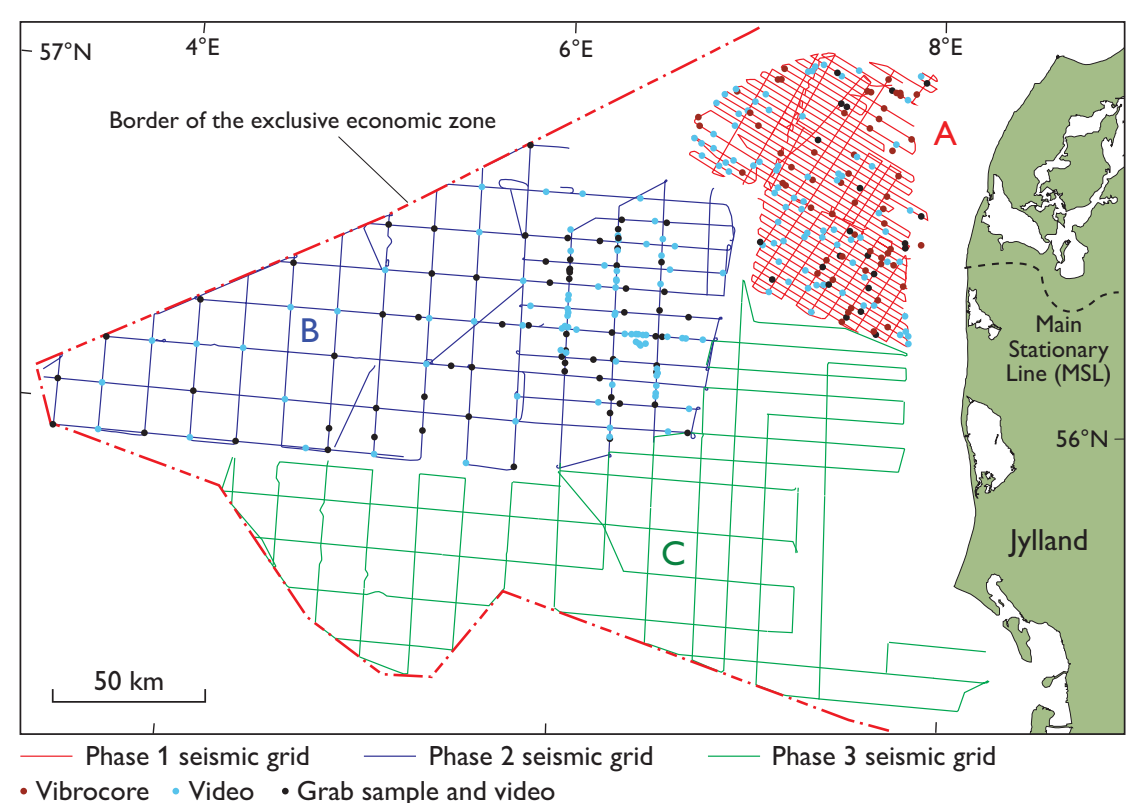

- Vibrocore . Video - Grab sample and video 


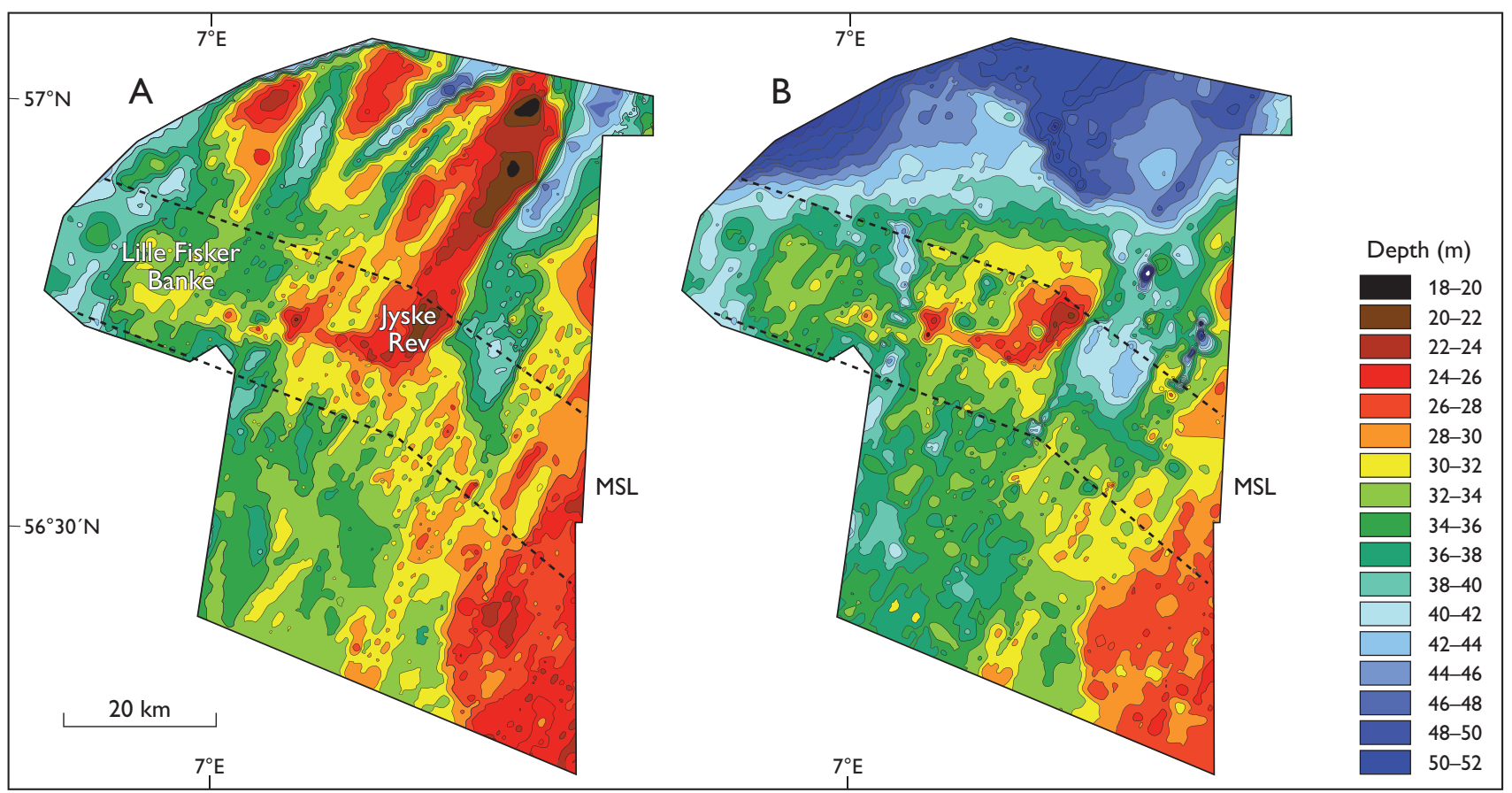

Fig. 2. Bathymetry and palaeo-morphology of the phase 1 area (Fig. 1), off north-west Jylland. A: Bathymetry. B: Palaeo-morphology in metres below present sea level of the pre-Holocene transgression surface. The Weichselian Main Stationary Line (MSL) is located in the Lille Fisker Banke - Jyske Rev area, between the stippled lines.

The pre-Quaternary surface is close to the seabed in the phase 1 area (Figs 3, 4; Nielsen et al. 2008) where it is overlain by a few tens of metres of Quaternary sediments. Thicker Quaternary deposits are found in local depressions connected with salt domes and in N-S-trending buried tunnel valleys that are incised into the pre-Quaternary deposits (Huuse \& Lykke-Andersen 2000). The Quaternary sediments overlie Miocene sand and clay, Danian limestone and locally Cretaceous chalk.

The Quaternary stratigraphy in the North Sea is poorly known, but south of the MSL Elsterian and Saalian till deposits have been identified on the seismic sections and in sediment cores in a situation similar to that found in the onshore hill islands in western Jylland. To some extent the deeply incised valleys are filled with pre-Weichselian sand and Eemian marine silt and sand (Figs 3, 4).

To a large extent the Weichselian deposits are related to the MSL. They are partly seen as glaciotectonic deformations in the sparker data, and partly as till deposited below and at the margin of the ice sheet. Glaciofluvial sand and gravel are located in depressions in the Weichselian landscape and proximal to distal sandur sediments overlying glacial deposits south of the MSL (Figs 3, 4).

Late glacial marine deposits overlie the glacial deposits at present water depths greater than $40 \mathrm{~m}$, which reflects the relative sea level around 17000 years BP (Leth 1996), shortly after the last deglaciation (Fig. 3). From c. 17000 years BP the relative sea level dropped to reach a minimum of about $50 \mathrm{~m}$ b.s.l. at $c .11000$ years BP. At that time only the northernmost part of the phase 1 area was below sea level (Fig. 2B) and a widespread hiatus is seen that lasted until submergence in connection with the Holocene transgression.

The relative sea level rose continuously from $c .11000$ to c. 6000 years BP to reach a maximum level at $1-3 \mathrm{~m}$ above the present sea level. Over the past 6000 years the relative sea level fell to its present level. The Holocene deposits can be divided into four units:

Table 1. Details of phases 1-3

\begin{tabular}{lccccc}
\hline Phase & Survey grid $(\mathrm{km})$ & Acoustic profiles $(\mathrm{km})$ & Vibrocores & Grab samples & Video data \\
\hline 1 & $2 \times 5$ & c. 3000 & 60 & 24 & 85 \\
2 & $7 \times 7 * / 7 \times 15^{*}$ & c. 3000 & - & 31 & 67 \\
3 & $7 \times 7$ & c. 2500 & - & - & - \\
\hline
\end{tabular}

* eastern area, ${ }^{\#}$ western area. 
Fig. 3. Seabed surface sediments in the phase 1 area (Fig. 1). The location of the geological profile (Fig. 4) is shown with a red stippled line. The inset diagram is a model of relative sea-level changes after the last deglaciation in the study area.

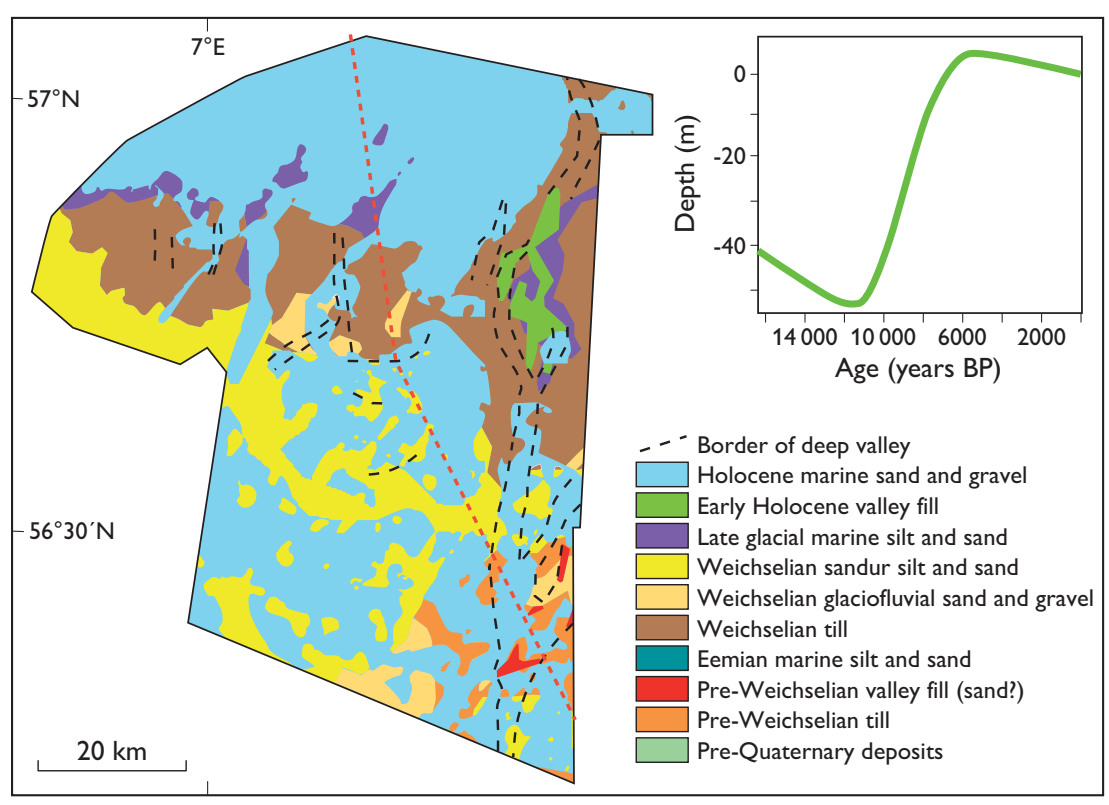

Early Holocene giant tidal sand ridge deposits. The giant tidal sand ridges are connected to the MSL which trends NNE-SSW and attains heights up to $20 \mathrm{~m}$ (Figs 2-4). The architecture implies that the ridges were formerly connected to the shore and formed by tidal currents during the Holocene sea-level rise, mostly by trapping of sediment within tidal eddies generated by headlands or flow convergence. Similar giant sand ridges related to Holocene sea-level rise have been reported from the English Channel (Reynaud et al. 2003).

Early Holocene fine-grained marine and fjord sediments. Incised valleys formed in the easternmost part of the phase 1 area during the lowstand period and during the initial part of the Holocene transgression (Fig. 3). Fine-grained marine sediments were deposited in such valleys in protected areas east of Jyske Rev, and brackish fine-grained sedimentation took place in palaeo-fjords similar to the present Limfjorden (Agger Clay; Leth 1996).

Holocene beach ridge and spit deposits. These accumulations formed during the progressive transgression when the glacial deposits were isolated as islands in the open sea. Erosion, transport and deposition led to the formation of beach deposits on the lee side of Jyske Rev.

Sub-recent to recent mobile sand. Around 8000-7000 years ago the shallow parts $(18-20 \mathrm{~m}$ b.s.l.) of the phase 1 area were transgressed by the sea. The present wave system and the Jutland Current developed (Gyllencreutz et al. 2006), which resulted in the formation of mobile sand waves and major sand banks in the Jyske Rev and Lille Fisker Banke region. The mobile sand deposits reached several metres in thickness and the bedforms can have wavelengths of over $100 \mathrm{~m}$.

\section{Potential for raw material}

We have identified a number of stratigraphical units that could be of interest to the sand and gravel industry. PreWeichselian sand in buried tunnel valleys is of potential interest in areas where no or little cover sediment is found.

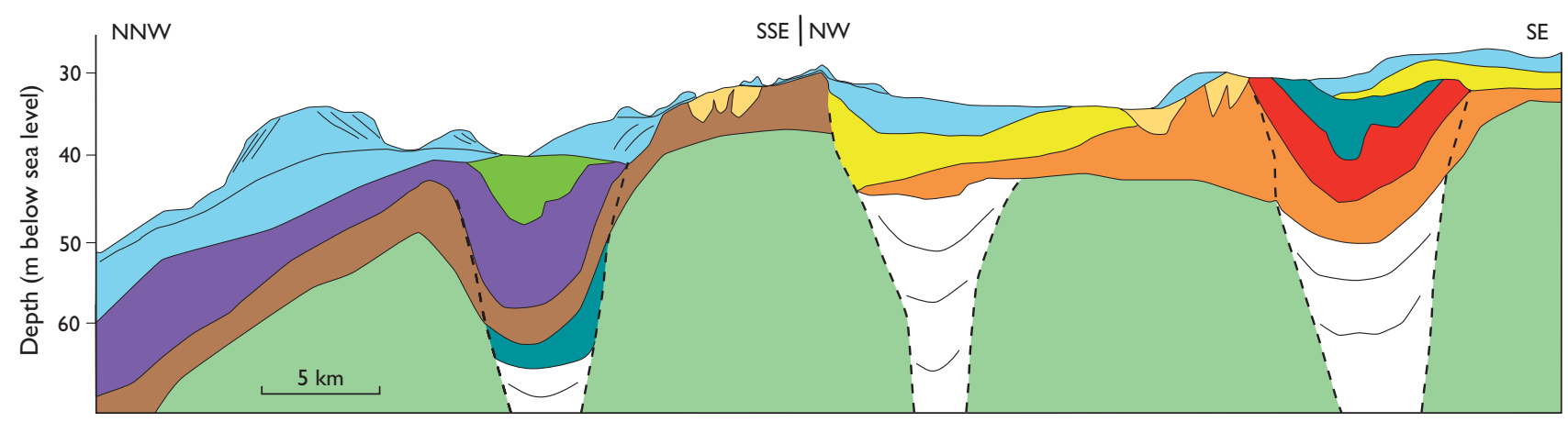

Fig. 4. NW-SE geological profile through the phase 1 area (Fig. 1) covered in the first phase. For legend and location of profile see Fig. 3. 
This is seen in the south-eastern part of the phase 1 area, but little is known about the volume and quality of the material accumulated in the tunnel valleys.

Weichselian glaciofluvial sand and gravel deposits along the MSL are of great interest as a resource for concrete production. However, this resource occurs only sporadically and is often covered by several metres of Holocene sediments.

Giant Holocene sand ridges in the north-western part of the phase 1 area are the most noteworthy sand resource in the region because of their enormous volume of around $8 \times 10^{9}$ $\mathrm{m}^{3}$. The resource is easily accessible and consists of mediumgrained sand that is well suited for land reclamation, beach nourishment and concrete production.

Drowned coastal deposits are the traditional dredged resource in the Jyske Rev area. This resource consists of highquality sand and gravel for concrete production as the high energy level during erosion and transport of the sediments has removed the light particles.

Recent mobile sand is often deposited in sand waves and the sediment consists of well-sorted, medium-grained sand that is excellent for beach nourishment. However, before this resource is removed it is crucial to ensure that the sand waves are not part of the present sand budget of the coast.

\section{Geological seabed units as bottom types and possible sand-eel fishery areas}

Bottom-type mapping was part of the seabed mapping task for the Danish Nature Agency. Since the seabed sediments form the habitat for marine benthic organisms and are of vital importance to the distribution of marine life, the seabed sediments have been used for mapping the dominant bottom types.

A number of additional parameters such as light penetration, salinity and temperature influence the distribution of faunal types, but a close link between till deposits on Jyske Rev and the Natura 2000 code 1170 stone reef type (Boedeker et al. 2006) is obvious. A close link is also seen between giant sand ridges and the Natura 2000 code 1110 sand bank type.

The mapping of the geological unit giant sand ridges as sand banks was compared with the distribution of sand-eel fishing grounds in the Jyske Rev and Lille Fisker Banke areas (Jensen et al. 2011) and a nearly perfect match was found.

\section{Concluding remarks}

We have developed a geological model that can form the basis of combined mapping of raw material and marine bottom types in the Lille Fisker Banke and Jyske Rev areas. Weichselian glaciofluvial deposits, early Holocene giant, tidal sand ridges, Middle Holocene drowned, coastal sand and gravel deposits and sub-recent to recent mobile sand waves and banks form potential or substantiated raw material geological units.

Examples of dominant bottom types are the Jyske Rev till deposits that are classified as a stone reef of the seabed type, and the early Holocene giant tidal sand ridges that represent a sand bank type. Sand-eel fishing grounds have been used as an example of the close linkage between geology, bottom types and fish habitats.

\section{Acknowledgement}

The Danish Nature Agency is thanked for permission to publish the paper.

\section{References}

Boedeker, D., Krause, J.C. \& von Nordheim, H. 2006: Interpretation, identification and ecological assessment of the NATURA 2000 habitats 'sandbank' and 'reef'. In: von Nordheim, H., Boedeker, D. \& Krause, J.C. (eds): Progress in marine conservation in Europe, NATURA 2000 sites in German offshore waters, 47-64. Berlin: Springer.

Gyllencreutz, R., Backman, J., Jakobsson, M., Kissel, C. \& Arnold, E. 2006: Postglacial paleoceanography in the Skagerrak. The Holocene 16, 975-985.

Houmark-Nielsen, M. \& Kjær, K.H. 2003: Southwest Scandinavia 40-15 kyr BP: palaeogeography and environmental change. Journal of Quaternary Science 18, 769-786.

Huuse, M. \& Lykke-Andersen, H. 2000: Overdeepened Quaternary valleys in the eastern Danish North Sea: morphology and origin. Quaternary Science Reviews 19, 1233-1253.

Jensen, H., Rindorf, A., Wright, P.J. \& Mosegaard, H. 2011: Inferring the location and scale of mixing between habitat areas of lesser sandeel through information from the fishery. ICES Journal of Marine Science 68, $43-51$.

Leth, J.O. 1996: Late Quaternary geological development of the Jutland Bank and the initiation of the Jutland Current, NE North Sea. Geological Survey of Norway Bulletin 430, 25-34.

Nielsen, T., Mathiesen, A. \& Bryde-Auken, M. 2008: Base Quaternary in the Danish parts of the North Sea and Skagerrak. Geolological Survey of Denmark and Greenland Bulletin 15,37-40.

Reynaud, J.-Y., Tessier, B., Auffret, J.-P., Berné, S., de Batist, M., Marsset, T. \& Walker, P. 2003: The offshore Quaternary sediment bodies of the English Channel and its Western Approaches. Journal of Quaternary Science 18, 361-371.

Authors' address

Geological Survey of Denmark and Greenland, ØsterVoldgade 10, DK-1350 Copenhagen K, Denmark. E-mail: jbj@geus.dk 